\title{
Currency linkages among ASEAN
}

\begin{abstract}
The purpose of this study is to examine the potential linkages among ASEAN-5 currencies, in particular the possibility of a Singapore dollar bloc during the pre- and post-crisis periods by using the Johansen multivariate cointegration test and the Granger causality test. Significant nonstationarity and the presence of unit roots were documented for each currency under both study periods. Using ASEAN-4 exchange rates against the Singapore dollar, the Johansen cointegration test showed that there was no cointegrating relationship during the pre-crisis period. However there were two statistically significant cointegrating vectors among ASEAN exchange rates for the post-crisis period. These findings imply that there is low financial integration before the crisis, but that ASEAN countries are financially more integrated after the crisis. This finding also indicates increasingly role of the Singapore dollar in ASEAN. Therefore, the Singapore dollar may be a possible candidate as the common currency for ASEAN. The analysis is repeated by adding the US dollar to the model. The finding ascertains the influence of the US dollar on ASEAN currencies before the crisis.
\end{abstract}

Keyword: Exchange rate; Cointegration; Granger causality; ASEAN 